\title{
PITIRIASIS ROSEA: MANIFESTASI KLINIS DAN TATALAKSANA
}

\author{
Muhammad Akbar Hanardi, Faris Rizki Ardhan, Visakha Vidyadevi Wiguna, \\ Dhila Thasliyah, Ni Putu Yunandari \\ Fakultas Kedokteran, Universitas Mataram, Indonesia. \\ Email: muhammadakbarhanardi@gmail.com, farisardhn@gmail.com, \\ visakhawiguna@gmail.com,d.thasliyah@gmail.com, putuyunandari@gmail.com
}

\begin{abstract}
Abstrak:
Pitiriasis rosea (PR) merupakan kelainan kulit papuloskuamosa yang ditandai dengan munculnya bercak-bercak ruam pada kulit dengan lesi multipel disertai dengan pola khas pada lipatan tubuh dan tungkai. Studi di Afrika mengenai PR menunjukkan bahwa epidemiologi pasien dengan PR sebesar 2,2\% hingga 4,8\%. Insiden kejadiannya sekitar 170 kasus per 100.000 orang per tahun dan biasanya menyerang orang berusia 10 sampai 35 tahun. Manifestasi klinis pada PR dapat berupa lesi tunggal yang lebih besar, berukuran sekitar 2 hingga 10 sentimeter, biasanya dimulai dari munculnya ruam yang meluas hingga dua minggu. Lesi awal ini biasa dikenal dengan 'herald patch', paling sering muncul pada lipatan tubuh, dan kemudian akan terjadi erupsi sekunder, lesi ini mirip dengan herald patch tetapi lebih kecil. Pendistribusian lesi ini biasanya mengikuti pola garis pembelahan kulit pada punggung yang disebut sebagai "Christmas tree pattern". Faktor risiko PR seperti infeksi COVID-19, reaktivasi virus herpes, faktor lingkungan, dan faktor kehamilan. Pengobatan bertujuan mengurangi gejala yang terdiri dari antihistamin, antibiotik atau kortikosteroid. Dalam beberapa kasus, asiklovir dapat digunakan untuk mengobati gejala dan mengurangi lamanya penyakit. Fototerapi ultraviolet juga dapat dipertimbangkan untuk kasus yang parah.
\end{abstract}

Kata kunci: Pitiriasis Rosea; Papuloskuamosa; Covid-19; Asiklovir

\begin{abstract}
Pitiriasis rosea $(P R)$ is a papulosquamous disorder with appearance of multiple, discrete patchesof skin rash in a distinctive pattern over the trunk and limbs. Epidemiologic studies on PR in Africa showed 2,2\% to 4,8\% dermatologist patient have a PR. The incidence is 170 cases per 100,000 persons per year and It typically affects persons 10 to 35 years of age. The clinical presentation of $P R$ can be a single larger lesion, measuring about 2 to 10 centimetres, usually precedes the widespread rash for up to two weeks. This initial lesion, also known as the 'herald patch', most commonly appears on the trunk, and then the secondary eruption occurs. Lesions are similar to the herald patch but smaller. Their distribution commonly follows the skin cleavage lines in what is referred to as the 'Christmas tree pattern'. The risk factor of PR such as COVID-19 infection, herpes virus reactivation, environmental factors, and pregnancy factors. Treatment is aimed at controlling symptoms and consists of
\end{abstract}

Copyright holder: Muhammad Akbar Hanardi, Faris Rizki Ardhan, Visakha Vidyadevi Wiguna, Dhila Thasliyah, Ni Putu Yunandari (2022)

DOI : $10.54543 /$ fusion.v2i1.131

Published by

: Rifa Institute 
antihistamines, antibiotics or corticosteroids. In some cases, acyclovir can be used to treat symptoms and reduce the length of disease. Ultraviolet phototherapy can also be considered for severe cases.

Keywords: Pitiriasis rosea; papuloskuamosa; covid-19; acyclovir

Diterima: 15-12-2021 Direvisi: 12-01-2022 Diterbitkan: 20-01-2022

\section{Pendahuluan}

Pitiriasis rosea (PR) merupakan kelainan papuloskuamosa yang pertama kali dijelaskan oleh Robert Willan dengan terminologi lain pada tahun 1798, yakni seperti pitiriasis circinata, roseola annulata dan herpes tonsurans maculosus (Mahajan et al., 2016). Pitiriasis rosea berasal dari kata Latin pityrus yang berarti dedak, hal ini menunjukkan adanya sisik halus pada lesi kulit dan kata rosea yang berarti mawar yang menggambarkan warna khas dari ruam (Contreras-Ruiz et al., 2019).

Kondisi kulit dengan PR dapat sembuh sendiri dan muncul sebagai papula bersisik pada tubuh dan tungkai (Villalon-Gomez, 2018). Diagnosis PR secara global berkisar 0,3\% hingga 1,2\% dari semua pasien dermatologis. Studi epidemiologi mengenai PR yang telah dilakukan di Asia dan Afrika menunjukkan prevalensi PR lebih sering terjadi di Afrika, yakni berkisar antara 2,2\% hingga 4,8\% pasien dermatologis. Insiden kejadian PR secara global adalah 170 kasus per 100.000 orang per tahun dan memuncak antara usia 10 hingga 35 tahun (Vanravenstein and Edlund, 2017; VillalonGomez, 2018).

Beberapa penelitian melaporkan bahwa laki-laki dan perempuan memiliki perbandingan insiden yang sama sedangkan penelitian lainnya melaporkan bahwa kejadian PR sering terjadi pada wanita. Hal ini didukung dengan studi epidemiologi yang melaporkan perbandingan rasio antara laki-laki dan perempuan yang mengalami PR yakni 1:1,1-1,4. Tetapi, kejadian PR di Singapura dan India berbanding terbalik dengan studi epidemiologi yang ada, didapatkan PR lebih sering terjadi pada laki-laki (Villalon-Gomez, 2018; Contreras-Ruiz et al., 2019).

Data variasi musiman pada kejadian PR saling bertentangan dan bervariasi antar wilayah geografis yang berbeda, tetapi kejadian musiman terlihat paling tinggi terjadi selama musim dingin, dan beberapa penelitian menyebutkan pada musim semi dan musim gugur (Contreras-Ruiz et al., 2019). Selain variasi musim, kejadian PR pun cenderung terjadi secara berkelompok, terutama didaerah yang individunya berkontak dekat (Vanravenstein and Edlund, 2017). Tujuan studi tinjauan systematic review ini yaitu untuk dapat mengetahui gambaran klinis, faktor risiko, dan tatalaksana pada pitiriasis rosea.

\section{Metode penelitian}

Metode yang digunakan dalam penulisan ini menggunakan systematic review dari berbagai jenis sumber yang berasal dari jurnal ilmiah. Pencarian sumber artikel dilakukan melalui portal online publikasi jurnal seperti National Center for 
Muhammad Akbar Hanardi, Faris Rizki Ardhan, Visakha Vidyadevi Wiguna, Dhila Thasliyah, Ni Putu Yunandari

Biotechnology Information / NCBI (ncbi.nlm.nih.gov) dan Google Scholar (scholar.google.com). Kata kunci yang digunakan "Pityriasis Rosea", "Papulosquamous", “Covid-19”, “Acyclovir"

\section{Hasil dan Pembahasan}

\section{A. Gambaran Klinis}

Gejala dari PR sering dimulai dengan adanya plak bersisik besar (herald patch atau mother herald) berukuran sekitar 2-10 cm pada batang tubuh atau leher, yang sering muncul 1-2 minggu sebelum erupsi terjadi pada 50\% hingga $90 \%$ pasien dengan PR. Lesi ini eritematosa, ovoid, agak menonjol, dan memiliki lingkaran bersisik di sekitar lesi. Beberapa individu mungkin tidak menyadari herald patch jika terletak di area yang tidak mudah terlihat. Oleh karena itu, gambaran awal mungkin tidak terjadi ketika herald patch muncul tetapi setelah ruam yang lebih menyebar (Vanravenstein and Edlund, 2017).

Setelah munculnya herald patch, difus berkembang (erupsi sekunder) berharihari hingga berminggu-minggu menjadi lesi papuloskuamosa bersisik yang lebih kecil yaitu sekitar 5-10 mm yang terletak terutama di paha atas, lengan atas, batang tubuh dan mengikuti langer lines pada punggung, dan membentuk gambaran seperti pohon Natal atau christmas-tree pattern (Drago et al., 2016; Mahajan et al., 2016;).

Erupsi biasanya didahului oleh gejala awal berupa nyeri tenggorokan, gangguan gastrointestinal, demam, sakit kepala, anoreksia, dan artralgia (Mahajan et al., 2016; Vanravenstein and Edlund, 2017). Pruritus muncul pada 75\% pasien, dengan $50 \%$ melaporkan pruritus ringan sampai sedang dan $25 \%$ melaporkan pruritus berat, dan sisanya 25\% dari pasien melaporkan tidak adanya pruritus (Vanravenstein and Edlund, 2017).

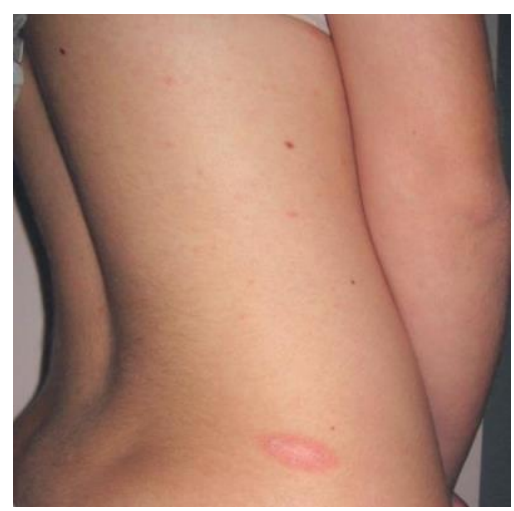

Gambar 1. Gambaran plak bersisik besar atau herald patch yang merupakan gambaran khas dari PR dikutip dari Contreras-Ruiz et al., 2019. 


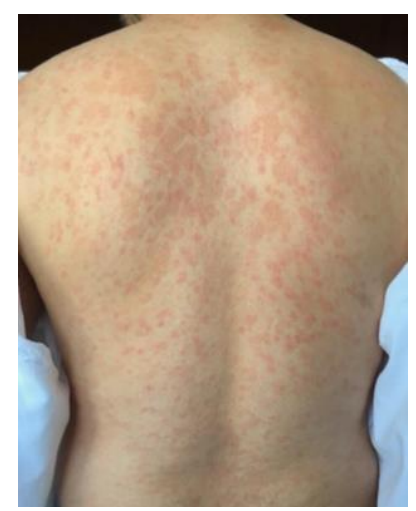

Gambar 2. Gambaran erupsi sekunder dari PR yang membentuk gambaran Christmas tree pattern dikutip dari Contreras-Ruiz et al., 2019.

\section{B. Patogenesis}

Penyebab terjadinya PR hingga kini belum diketahui pasti. Tetapi, beberapa teori menyebutkan bahwa agen infeksi, terutama virus merupakan etiologi utama dari kejadian PR. Hal ini dinilai dari penemuan partikel virus intranuklear dan intrasitoplasma, serta peningkatan kadar cluster of differentiation 4 (CD4) dan sel langerhans di dermis kulit penderita PR yang menandakan adanya infeksi oleh virus (Vanravenstein and Edlund, 2017; Villalon-Gomez, 2018). Virus yang dicurigai dapat menyebabkan PR adalah human herpesvirus (HHV)-6 dan/atau HHV-7. HHV-6 lebih sering menyerang anak-anak usia dua tahun, sedangkan HHV-7 menyerang anak pada usia enam tahun (Villalon-Gomez, 2018). Tes seropositif yang dilakukan di Amerika Serikat, didapatkan 80-90\% pada orang dewasa terdapat virus HHV-6 dan/atau HHV-7. Hal ini dapat menunjukkan bahwa virus tersebut lazim pada populasi dewasa. HHV-6 dan HHV-7 biasanya didapat selama masa kecil. HHV-6 dapat ditularkan dari ibu ke janin melalui plasenta, saliva atau ASI. HHV-7 juga dapat ditularkan melalui saliva. Selain itu, virus tersebut juga dapat diperoleh selama masa kanak-kanak, biasanya diperoleh di kemudian hari. Virus ini tertidur sampai mereka diaktifkan kembali selama penyakit virus lainnya, kehamilan, penyakit kronis, atau pada pasien dengan gangguan kekebalan (Vanravenstein and Edlund, 2017).

\section{Faktor Risiko}

Penyebab terjadinya PR belum diketahui pasti, tetapi terdapat bebera faktor risiko yang dapat meningkatkan terjadinya kejadian $\mathrm{PR}$, faktor risiko tersebut yakni sebagai berikut:

\section{Infeksi Coronavirus Disease 2019 (COVID-19)}

Dilaporkan bahwa terjadi peningkatan lima kali lipat dalam jumlah kasus PR selama pandemik severe acute respiratory syndrome corona virus 2 (SARS CoV-2). Hal ini bisa dikarenakan reaktivasi infeksi virus herpes dan faktor psikoemosional selama pandemi. Peran SARS CoV-2 sebagai pemicu timbulnya PR secara langsung oleh tindakan soliter maupun secara tidak langsung oleh induksi respon inflamasi dari hiperaktivitas sitokin proinflamasi atau kemungkinan reaktivasi dari HHV-6 dan HHV7 (Birlutiu et al, 2021). 
Muhammad Akbar Hanardi, Faris Rizki Ardhan, Visakha Vidyadevi Wiguna, Dhila Thasliyah, Ni Putu Yunandari

Keterlibatan kulit kira-kira sekitar 2-20,4\% dari semua pasien COVID-19. Di China, manifestasi kutaneus telah dilaporkan pada 0,2\% pasien yang terinfeksi oleh COVID19, dan 18 dari 88 pasien dari Italia. Keterlibatan kulit yang paling banyak dilaporkan manifestasinya adalah ruam eksantematosa, urtikaria, vesikel, petekie, dan edema hemoragik akut pada bayi. Selain itu, pada PR dapat juga ditemukan gambaran khas herald patch dengan collarette of trailing scale yang diikuti dengan lesi diseminata yang lebih kecil (Paolino et al, 2021; Ehsani et al, 2020).

Manifestasi kulit PR bisa menjadi gejala awal atau prodromal dari infeksi SARS-CoV-2. Pada fase akut COVID-19 didapatkan tampilan yang lebih eritematosa dan purpura sebagai indikasi keadaan inflamasi umum yang terkait dengan SARS-CoV2. Infeksi SARS-CoV-2 memainkan peran trans-aktivasi yang memicu reaktivasi dari HHV-6, HHV-7 dan virus epstein-barr (EBV) sehingga menyebabkan PR (Paolino et al, 2021).

Dilaporkan bahwa asam deoksiribonukleat (DNA) virus dan aviditas tinggi pada antibodi HHV-6 dan EBV terdeteksi dalam kasus COVID-19 terkait PR, hal ini menunjukkan bahwa SARS-CoV-2 telah memicu reaktivasi virus berantai. Dalam beberapa kasus, antibody terhadap HHV-6 atau HHV-7 serta DNA virus dalam plasma dan profil peripheral blood mononuclear (PBMC) terdeteksi. Temuan ini menunjukkan bahwa reaktivasi virus yang diinduksi kekebalan merupakan penyebab utama. Seperti yang diusulkan beberapa peneliti, munculnya respon imun spesifik terhadap agen infeksius yang dipicu oleh vaksin Pfizer BioNTech dapat mengganggu kontrol yang diperantarai sel pada infeksi laten seperti HHV-6 atau HHV-7 (Busto-Leis et al, 2021).

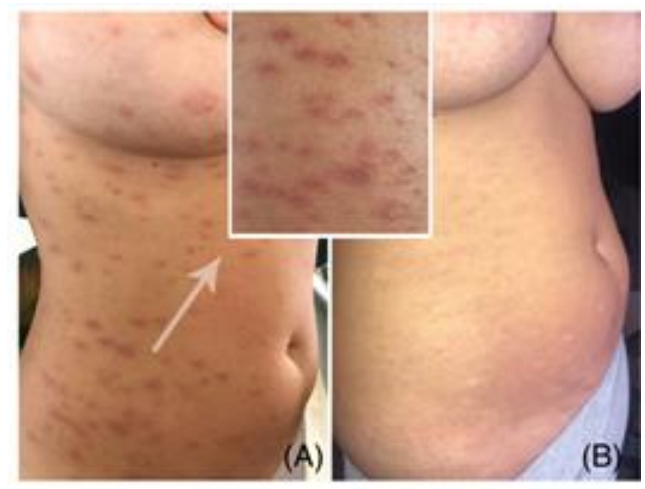

Gambar 3. Gambaran Penderita COVID-19 dengan PR dikutip dari Ehsani et al, 2020.

Gambar A. Timbulnya gejala kulit "herald patch" dengan eritematosa bersisik di payudara kanan. Lima hari kemudian, timbul lesi dengan tipe papul dan plak dibadan seperti "Christmas tree".

Gambar B. Setelah pengobatan sistemik steroid, antihistamin dan krim pelembab sudah terjadi proses penyembuhan lesi kulit.

\section{Reaktivasi virus herpes}

Pitiriasis Rosea (PR) diduga dapat disebabkan oleh reaktivasi virus yang laten, bukan hanya infeksi virus primer. Penelitian dari Chu et al. menyatakan bahwa kelompok dengan PR temporal berkaitan dengan reaktivasi virus. Pitiriasis rosea adalah eksantema akut yang diduga kuat disebabkan oleh reaktivasi HHV-6 dan HHV-7 
(Dursun \& Temiz, 2020; Engelmann et al., 2018; Hayta, et al., 2019). HHV-6 dan HHV-7 biasanya ditularkan pada dua tahun pertama kehidupan (roseola infantum) kemudian menetap di kelenjar saliva dan darah pasien sehingga dapat menyebabkan infeksi laten (Dursun \& Temiz, 2020). Aktivasi imunitas seluler dan respons induksi inflamasi diduga terlibat dalam patogenesis dari PR (Engelmann et al., 2018).

Pada penelitian yang dilakukan Hayta, et al., didapatkan hubungan positif antara PR dan kelompok virus herpes simpleks 1 (HSV-1). Interaksi yang ditimbulkan infeksi virus ini dengan PR mungkin sama dengan HHV-6. Hal ini mungkin terjadi dikarenakan koinfeksi dengan beberapa spesies virus. Sebagai tambahan, infeksi HSV-1 sangat menular, umum terjadi dan endemik di seluruh dunia. Inkubasi dan durasi infeksi HSV-1 yang singkat diduga menyebabkan tidak ada interval waktu yang cukup untuk menjelaskan interaksi yang terjadi antara infeksi PR dan HSV-1 (Hayta, et al., 2019).

Salah satu faktor penyebab reaktivasi virus Herpes adalah coronavirus. Selama masa pandemi, hal yang menarik yang ditemukan bahwa tingkat pasien PR yang melakukan rawat jalan dermatologi pada tahun 2020 bertambah hingga 5 kali lipat dibandingkan dengan periode yang sama di tahun 2019. Studi ini merupakan studi pertama yang menunjukkan peningkatan pasien PR dan hubungannya dengan COVID19. Seiring dengan pandemi COVID-19 diperkirakan bahwa reaktivasi HHV-6 dapat menjelaskan peningkatan kasus PR (Dursun \& Temiz, 2020). Pemicu reaktivasi lain yang mungkin adalah tekanan psikologis (stres) yang terjadi (Dursun \& Temiz, 2020; Engelmann et al., 2018).

\section{Faktor Lingkungan}

Penelitian telah menunjukkan bahwa virus tertentu lebih aktif ketika kelembapan meningkat. Insiden PR meningkat secara signifikan ketika kelembapan lebih tinggi, namun tidak dipengaruhi oleh suhu. Hal ini juga sejalan dengan fakta bahwa HHV mungkin lebih aktif pada kondisi kelembaban yang meningkat. Kelembapan adalah faktor musiman yang penting dalam perkembangan PR (Hayta, et al., 2019).

\section{Kehamilan}

Beberapa penelitian telah menemukan bahwa pasien dengan PR memiliki tingkat HSV-6 dan HSV-7 yang lebih tinggi terdeteksi di kulit mereka, hal ini menunjukkan bahwa infeksi virus ini mungkin memiiki efek kausal pada perkembangan PR. Beberapa penelitian menemukan reaktivasi HSV-6 selama kehamilan. Namun hubungan antara infeksi virus dan gambaran klinis PR belum ditetapkan. Wanita hamil memiliki peluang terkena PR sebanyak 18\%. Terutama 15 minggu awal kehamilan perlu dihindari kontak dengan pasien yang menderita PR. Sebanyak 66\% wanita hamil mengalami PR selama trimester kehamilan kedua (13-28 minggu).

Sedangkan hanya 19\% wanita hamil mengalami PR pada trimester pertama dan $10 \%$ trimester ketiga. Pitiriasis rosea yang terjadi pada trimester pertama mempunyai prognosis lebih buruk jika dibandingkan dengan wanita yang mengalaminya pada trimester kedua dan ketiga. Beberapa peneliti mencatat bahwa PR yang terjadi di kehamilan memiliki kemungkinan lebih besar untuk menghasilkan efek samping pada 
Muhammad Akbar Hanardi, Faris Rizki Ardhan, Visakha Vidyadevi Wiguna, Dhila Thasliyah, Ni Putu Yunandari

janin seperti berat bayi lahir rendah (BBLR) dan prematur (Loh dan Cohen, 2016; Song et al, 2019).

Mual dan muntah adalah kondisi yang paling umum terjadi pada ibu hamil. Penggunaan ondansetron dalam tatalaksana mual dan muntah sering diberikan dengan dosis yang dianjurkan adalah $4 \mathrm{mg}$ setiap 8 jam untuk kasus mual muntah sedang dan 4$8 \mathrm{mg}$ setiap 8 jam untuk kasus mual muntah parah dan hiperemesis gravidarum. Salah satu efek yang dapat ditimbulkan dalam penggunaan obat ondansetron yaitu erupsi obat fikstum. Hal ini dikarenakan adanya reaksi obat pada kulit yang khas dengan plak sedikit warna merah kehitaman atau keunguan yang meninggalkan hiperpigmentasi. Lesi ini biasaya muncul dalam waktu 30 menit sampai 8 jam setelah pemberian obat dan akan sembuh sendiri dalam 7-10 hari setelah penghentian penggunaan obat.

Pada sebuah laporan kasus, ditemukan wanita hamil yang mengalami hiperemesis gravidarum. Obat yang diminum ialah ondansetron. Penggunaan obat ini mengurangi keluhan mual dan muntah yang dialami pasien. Namun penggunaannya dihentikan setelah muncul ruam-ruam pada kulit. Pasien di diagnosis PR akibat penggunaan ondansetron berdasarkan anamnesis dan pemeriksaan fisik dengan gejala yang khas yakni adanya herald patch, morfologi dan distribusi lesi, serta tidak adanya gejala selain pruritus. Dengan menggunakan skala Naranjo untuk menghitung kemungkinan adanya reaksi simpang obat, ondansetron dianggap sebagai kemungkinan penyebab PR pada kasus ini (Alame et al, 2018).

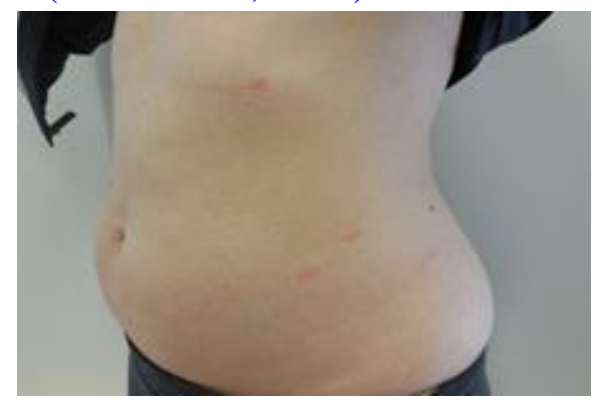

Gambar 4. Gambaran pasien wanita hamil dengan PR dikutip dari Loh dan Cohen, 2016.

Gambar dari seorang wanita dengan kehamilan 10 minggu terdapat lesi anular PR 2 minggu sebelumnya yang terdapat herald patch di perut bagian kanan.

\section{Manajemen Terapi}

\section{Terapi Farmakologi}

a. Kausatif

Etiologi pitiriasisi rosea (PR) belum diketahui secara spesifik. Pada suatu penelitian, mengatakan bahwa penyakit ini dalam disebabkan oleh infeksi virus. Virus yang paling banyak menyebabkan PR adalah jenis herpes virus (HHV-7 dan HHV-6), namun tidak meetup kemungkinan disebabkan oleh jenis virus lain seperti HHV-8, cytomegalovirus, dan Epstein-Barr Virus, serta faktor lain seperti imunologi.

Pada suatu penelitian meta analisis, mengatakan bahwa penggunaan terapi asiklovir memiliki efektifitas tinggi dalam mengurangi lesi kulit pada pasien dengan 
pitiriasis rosea. Selain itu, asiklovir direkomendasikan sebagai terapi awal dalam mengontrol pruritus, khususnya pada penyakit dengan lesi yang luas, sering kambuh, dan persisten. Dosis yang umum diberikan sebanyak 5 x $800 \mathrm{mg} /$ hari secara oral (Rodriguez, 2018).

Pada suatu penelitian meta-analisis, menyebutkan bahwa penggunaan asiklovir dapat menyembuhkan lesi eritema pada pitiriasis rosea dalam waktu 14 hari, serta dapat mengurangi timbulnya lesi kulit baru (Chang, 2018). Asiklovir bekerja secara intraseluler dan diubah menjadi asiklovir monofosfat oleh timidin kinase yang dikode oleh virus. Hal tersebut tidak terjadi pada sel yang tidak terinfeksi, sehingga asiklovir bersifat spesifik. Selanjutnya, asiklovir monofosfat diubah menjadi asiklovir trifosfat oleh enzim seluler dan akan menghambat polimerase DNA virus secara kompetitif (Rodriguez, 2018).

\section{b. Simtomatis}

Pada suatu uji klinis, menunjukkan pemberian asiklovir saja tidak berpengaruh secara signifikan dalam meredakan simtom pada PR, sehingga perlu adanya terapi simtomatis. Pada suatu penelitian meta-analisis, mengatakan bahwa terdapat beberapa terapi yang dapat diberikan untuk meredakan gejala yang timbul seperti pruritus yang parah, antara lain antibiotik, antihistamin, dan kortikosteroid (Rodriguez, 2018).

Antibiotik golongan makrolid, seperti eritromisin diduga dapat mengurangi simtom pada PR, namun hal ini belum terbukti signifikan secara klinis. Sebuah uji coba pseudo-randomised, double-blind, dengan jumlah sampel sebanyak 90 orang, menunjukkan hasil perbaikan gejala PR setelah enam minggu pada $73 \%$ dari mereka yang diobati dengan eritromisin oral, namun pada sampel yang lebih besar tidak menunjukkan hasil secara signifikan pada pengobatan PR (Villalon, 2018).

Namun, ada beberapa penelitian lain tentang kemanjuran dan kegunaan pengobatan PR, yang membuktikan efek menguntungkan dari antibiotik makrolida, terutama eritromisin dengan dosis $250 \mathrm{mg}$ empat kali sehari, yang secara signifikan dapat mempersingkat persistensi lesi kulit (Neneman et al., 2017).

Antihistamin secara oral dan pemberian steroid topikal, seperti calamine lotion direkomendasikan sebagai terapi simtomatis pada PR. Antihistamin oral yang dapat diberikan untuk meredakan gejala yaitu cetirizine dan diphenhydramine (Contreras-Ruiz et al., 2019).

\section{Terapi non-Farmakologi}

Salah satu terapi non-farmakologi yang dapat diterapkan pada penderita PR yakni fototerapi. Dalam Strategi pengobatan PR yaitu menyakinkan pasien dan membiarkan penyakitnya sembuh sendiri, Narrowband ultraviolet B Phototheraphy (NBUVB) merupakan pengobatan aman, hemat biaya, dan mudah tersedia.

NBUVB dalam pengobatan PR melakukan penekanan terhadap respon imun yang diperantarai sel pada PR dan memfasiltasi perbaikan gejala pasien. Variasi jumlah dan fungsi sel Langerhans di kulit setelah penyinaran UV bisa menjadi indikasi mekanisme kerja cahaya NBUVB di PR. 
Muhammad Akbar Hanardi, Faris Rizki Ardhan, Visakha Vidyadevi Wiguna, Dhila Thasliyah, Ni Putu Yunandari

\section{Kesimpulan}

Pitiriasis rosea adalah kondisi kulit yang dapat sembuh sendiri dan muncul sebagai papula bersisik pada tubuh dan tungkai dengan gambaran khas adanya herald patch dan membentuk gambaran Cristhmas tree pattern. Diagnosis PR secara global berkisar $0,3 \%$ hingga 1,2\% dari semua pasien dermatologis dengan insiden kejadian PR secara global adalah 170 kasus per 100.000 orang per tahun dan memuncak antara usia 10 hingga 35 tahun.

Gejala dari PR sering dimulai dengan adanya plak bersisik besar (herald patch), lalu mengalami erupsi sekunder menjadi lesi papuloskuamosa bersisik yang lebih kecil mengikuti langer lines pada punggung, dan membentuk gambaran seperti pohon Natal atau christmas-tree pattern. Penyebab terjadinya PR hingga kini belum diketahui pasti, beberapa teori menyebutkan bahwa agen infeksi, terutama virus merupakan etiologi utama dari kejadian PR.

Terdapat beberapa faktor risiko yang dapat meningkatkan terjadinya kejadian PR, seperti infeksi Coronavirus Disease 2019 (COVID-19), reaktivasi virus herpes, kehamilan dan kondisi lingkungan seperti tingkat kelembapan. Adapun tatalaksana farmakalogis dari PR ialah dengan pemberian antibiotik, antihistamin, dan kortikosteroid dan untuk non farmakalogi dapat diberikan fototerapi Narrowband ultraviolet B Phototheraphy (NBUVB) yang dapat menekan terhadap respon imun yang diperantarai sel pada PR dan memfasiltasi perbaikan gejala pasien. Variasi jumlah dan fungsi sel Langerhans di kulit setelah penyinaran UV bisa menjadi indikasi mekanisme kerja cahaya NBUVB di PR. 


\section{BIBLIOGRAFI}

Alame, M. M., Chamsy, D. J., \& Zaraket, H. (2018). Pitiriasis rosea-like eruption associated with ondansetron use in pregnancy. British journal of clinical pharmacology, 84(5), 1077-1080. Google Scholar

Birlutiu, V., Birlutiu, R. M., \& Iancu, G. M. (2021). Pitiriasis rosea Gibert triggered by SARS-CoV-2 infection: A case report. Medicine, 100(14), e25352. Google Scholar

Busto-Leis, J. M., Servera-Negre, G., Mayor-Ibarguren, A., Sendagorta-Cudós, E., Feito-Rodríguez, M., Nuño-González, A., Montero-Vega, M. D., \& Herranz-Pinto, P. (2021). Pitiriasis rosea, COVID-19 and vaccination: new keys to understand an old acquaintance. Journal of the European Academy of Dermatology and Venereology : JEADV, 10.1111/jdv.17301. Advance online publication. Google Scholar

Chang, H., Sung, C., \& Lin, M. (2018). The efficacy of oral acyclovir during early course of pitiriasis rosea: a systematic review and meta-analysis. Journal of Dermatological Treatment, 30(3), 288-293. Google Scholar

Contreras Ruiz, Jose \& Peternel, Sandra \& Gutiérrez, Carlos \& Čulav-Košćak, Ivana \& Reveiz, Ludovic \& Silbermann-Reynoso, Maria. (2019). Interventions for pitiriasis rosea. Cochrane Database of Systematic Reviews. 2019. 3. Google Scholar

Dursun, R., \& Temiz, S. A. (2020). The clinics of HHV-6 infection in COVID-19 pandemic: Pitiriasis rosea and Kawasaki disease. Dermatologic therapy, 33(4), e13730. Google Scholar

Ehsani, A. H., Nasimi, M., \& Bigdelo, Z. (2020). Pitiriasis rosea as a cutaneous manifestation of COVID-19 infection. Journal of the European Academy of Dermatology and Venereology : JEADV, 34(9), e436-e437. Google Scholar

Engelmann, I., Ogiez, J., Ogiez, L., Alidjinou, E. K., Lazrek, M., Dewilde, A., \& Hober, D. (2018). Relapsing Pitiriasis Rosea With HHV-7 Reactivation in an 11-Year-Old Girl. Pediatrics, 141(5), e20173179. Google Scholar

Hayta, S., Güner, R., Çam, S. and Akyol, M., 2019. The relationship between pitiriasis rosea, seasonal factors, and other herpetic infections: A time series analysis. Dermatologica Sinica, 37(3), p.134. Google Scholar

Loh, T. Y., \& Cohen, P. R. (2016). Pitiriasis rosea in pregnancy: report of a spousal occurrence and craniosynostosis in the healthy newborn. Dermatology practical \& conceptual, 6(3), 39-46. Google Scholar

Mahajan, K., Relhan, V., Relhan, A. K., \& Garg, V. K. (2016). Pitiriasis Rosea: An Update on Etiopathogenesis and Management of Difficult Aspects. Indian journal of dermatology, 61(4), 375-384. Google Scholar

Neneman, A., Mikiel, D., Adamski, Z., \& Bowszyc-Dmochowska, M. (2017). Pitiriasis rosea in a patient with retrovirus infection and a history of syphilis and positive results of infection with hepatitis A virus, hepatitis B virus and hepatitis $\mathrm{C}$ virus. Advances In Dermatology And Allergology, 3, 276-278. Google Scholar

Paolino, G., Di Nicola, M. R., Cantisani, C., \& Mercuri, S. R. (2021). Pitiriasis rosea infection in a COVID-19 patient successfully treated with systemic steroid and antihistamine via telemedicine: Literature update of a possible prodromal symptom of an underlying SARS-CoV-2 infection. Dermatologic therapy, e14972. Advance online publication. Google Scholar

Rodriguez-Zuniga, M., Torres, N., \& Garcia-Perdomo, H. (2018). Effectiveness of 
Muhammad Akbar Hanardi, Faris Rizki Ardhan, Visakha Vidyadevi Wiguna, Dhila Thasliyah, Ni Putu Yunandari

acyclovir in the treatment of pitiriasis rosea. A systematic review and metaanalysis. Anais brasileiros de dermatologia, 93(5), 686-695. Google Scholar

Song, J. and Chandy, S., 2019. ATYPICAL PITIRIASIS ROSEA: A REVIEW OF THE LITERATURE. European Journal of Pharmaceutical and Medical Research, 6(5), pp.145-149. Google Scholar

VanRavenstein, K., \& Edlund, B. J. (2017). Diagnosis and management of pitiriasis rosea. The Nurse practitioner, 42(1), Google Scholar

Villalon-Gomez JM. Pitiriasis Rosea: Diagnosis and Treatment. Am Fam Physician. 2018 Jan 1;97(1):38-44. PMID: 29365241. Google Scholar

First publication right:

Jurnal Syntax Fusion: Jurnal Nasional Indonesia

This article is licensed under:

(c) (†) (?) 